\title{
Creating regional infrastructure in the special economic zones of the Russian Federation to address the challenges of the Sustainable Development Goals
}

\author{
Elena Knyazeva, and Denis Zheriborov \\ Ural State University of Economics, 8 Marta st./ Narodnoj Voli st. 66/45, 620144 Yekaterinburg, \\ Russia
}

\begin{abstract}
Water resources are an integral part of energy, industry, food and human life. Water efficiency is given a special place in the area of achieving the Sustainable Development Goals (SDGs) promoted by the United Nations $(\mathrm{UN})$. Water is used everywhere in everyday life and in the manufacture of products, which leads to the depletion of the water potential of a country or an entire continent. Currently, companies are actively introducing new standards for water use, keeping records of water consumption, applying innovative technologies to provide water desalination and wastewater treatment. There is a shortage of drinking water in the world, especially in overpopulated countries and the southern regions of the planet. No state can solve water use issues on its own. Currently, countries are focusing on developing technologies for desalination and wastewater treatment plants. These industries are science-intensive, innovative and require raw materials, financial resources and policy favors from the states. On the territory of the Sverdlovsk region of the Russian Federation, all known types of common minerals were found, and a special economic zone the "Titanium Valley" also operates on this territory.
\end{abstract}

\section{Introduction}

Iintroduction of high-tech industries facilitates international trade and meets the Sustainable Development Goals of the United Nations (UN) [10]. Special economic zones (SEZ) are one of the institutions for the development of the regional financial system. The SEZ has certain special legal and financial conditions to attract domestic and foreign investors. Developing regional infrastructure projects in the SEZ is a priority issue for the regional authorities of the territorial subject of the Russian Federation

\section{Materials and Methods}

The article was prepared based on materials from the Scopus databases, the United Nations (UN) and other sources. The authors of the article analyze one of the promising areas that will develop and the implementation of which will allow solving some of the problems to achieve the Sustainable Development Goals. 


\section{Results and Discussion}

The production of innovative products is based on international cooperation, synergy of various branches of science and the availability of finance. At the same time, it should be noted that international cooperation is found in every country both at the macro and micro levels. The synergy of sciences also has a positive trend and dynamics. The issue of financing various innovative projects remains always open. Currently, states and large multinational companies are financing large innovative projects aimed at the transition to environmentally friendly, energy-saving and "green" technologies. This drive is determined by various factors, but it is not always possible for one state or a multinational corporation to allocate enough financial resources to achieve its goals

Capital and the system to which it has given its name was not designed by anybody in a coherent fashion, but neither can it be described as the product of natural evolution. To turn a simple object, promise or idea into capital, somebody must decide, which and whose assets shall be coded as capital; others must accept the coding, even yield to it. [1].

International cooperation is possible if all the parties interested in implementing a major project can come to an agreement. One of the institutions for attracting potential investors are special economic zones, which are located on the territory of a certain municipality. Municipal authorities are not always able to assess the positive and negative aspects of large international projects, which does not allow them to actively offer their services to investors, yielding this role to government ministries and departments. Policymakers usually face these decisions and trade-offs, and in many countries they have to conduct a cost-benefit analysis or assessment. The problem is that many of the costs and benefits are not traded in the markets, and politicians do not have any information about the preferences of society related to these non-market goods and services [7].

Another reason why municipalities do not actively participate in large international projects is the phenomenon of soft budget constraint (SBC) - an effect in the economy, which indicates that when making decisions related to the risks of insolvency, the authorities and large companies' management expect to receive financial assistance from the state. The SBC phenomenon arises when the financial decisions of local and regional government bodies are determined by the expectation that they will be saved if they have serious financial problems. [2]

The old paradigms of regional development argued that the reduction of territorial inequality can be achieved exogenously, for example, the export model will bring income to a certain region, which, after the initial temporary polarization, will increase the economy [3].

Each subject of the Russian Federation builds horizontal economic ties with foreign partners. Any interaction between regions should be considered at the following levels: 1 . Interaction between authorities and management; 2. Inter-municipal communications; 3. Business cooperation; 4. Contacts between specialized organizations (chambers of commerce and industry, etc.); 5. Inter-university dialogue; 5. Non-profit organizations.

It is important to note that when interacting, each of the parties tries to achieve the specific goals.

In the joint project, for example, for the construction of the SEZ "Titanium Valley" (Russia, Sverdlovsk region) the production of manufacturing equipment for water desalination and wastewater treatment allows solving several problems related to SDG.

The world market of water desalination by 2025 is estimated at more than US \$ 32 billion [11]. At the same time, according to forecasts, the volume of the market for wastewater treatment services by 2024 will reach 65.1 billion US dollars. Key manufacturers of this market are the following companies: Veolia (France), SUEZ (France), Xylem (USA), Ecolab (India), Evoqua Water Technologies (USA), Thermax (India) and WOG Group (USA), 
Golder Associates (Canada)), Envirosystems Inc. (Canada) and SWA Water Holdings (Australia) [12].

WASTEWATER TREATMENT SERVICES MARKET, BYREGION (USD BILLION)

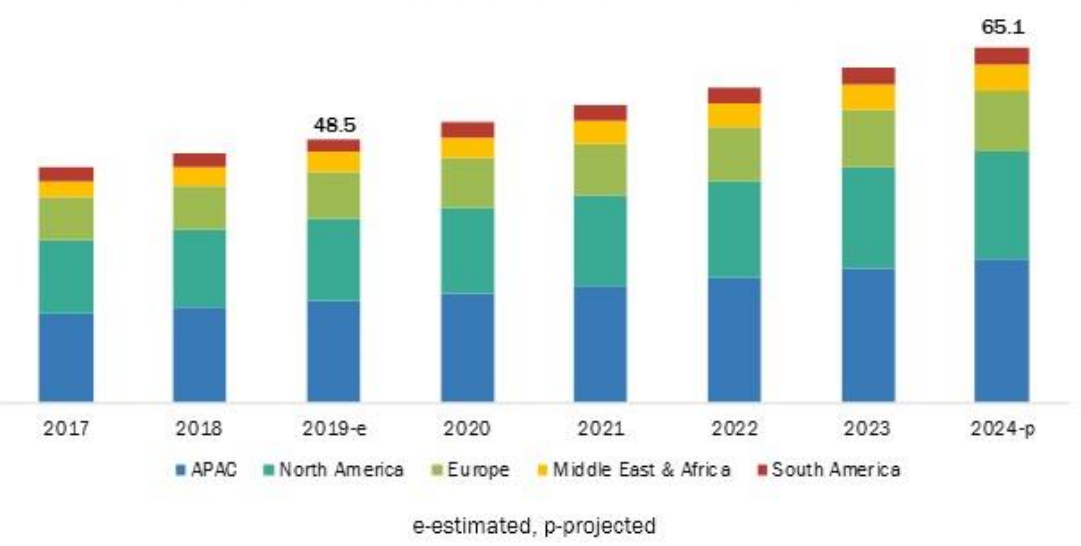

Fig. 1. Market size of wastewater treatment services, by type of service, 2017-2024 (USD million)

SEZ "Titanium Valley" should be considered as a possible platform for international cooperation in the field of water desalination and wastewater treatment, since there are titanium dioxide deposits in the Sverdlovsk region, and one of the world's largest titanium production facilities is located here. SEZ residents are offered a number of benefits and preferences, which makes it possible to speak about the uniqueness of the Titanium Valley for joint international projects.

The tax and customs benefits applied in SEZ "Titanium Valley" are presented in Table 1.

Table 1. Tax and customs benefits.

\begin{tabular}{|l|l|c|c|}
\hline & \multicolumn{1}{|c|}{ Type of tax } & $\begin{array}{c}\text { Total tax rate } \\
\text { in the Russian Federation }\end{array}$ & $\begin{array}{c}\text { On the territory } \\
\text { of SEZ }\end{array}$ \\
\hline \multirow{3}{*}{ Tax benefits } & Income tax & $20 \%$ & $2 \%$ \\
\cline { 2 - 4 } & Land tax & $1,5 \%$ & $0 \%$ \\
\cline { 2 - 4 } & Property tax & $2,2 \%$ & $0 \%$ \\
\cline { 2 - 4 } & Transport tax & Calculated depending on engine power & $0 \%$ \\
\hline \multirow{2}{*}{$\begin{array}{l}\text { Customs } \\
\text { privileges }\end{array}$} & Import duty & $5-20 \%$ & $0 \%$ \\
\cline { 2 - 4 } & Customs VAT & $10-20 \%$ & $0 \%$ \\
\hline
\end{tabular}

As part of the study on water use in the People's Republic of China, relationships were identified between water consumption, real output, reform and urbanization in instrumental assessment models. The economic growth experience in Guangzhou shows that the GDP and the popularization of water lead to more water consumption. As part of the study, proposals were put forward aimed at the work of policymaking government bodies. The proposals are as follows: (i) R\&D funds should be established to develop the technologies for distributed water resources; (ii) a subsidy policy must be carried out to develop water saving business models; (iii) an effective system of prices and regulated charges for water supply services must be created; (iv) investment in water utilities and the development of water stations needs to be scaled up. [4].

Based on this study, it can be assumed that the development of an international project for desalination plants and wastewater treatment plants in the SEZ "Titanium Valley" requires mutual interest of states, large national companies and investors.

To calculate the economic efficiency of international cooperation of SEZ "Titanium Valley" with a potential investor, we use the gravity model of international trade. The gravity 
model of international trade in the international economy is a model that, in its traditional form, predicts bilateral relations and trade flows based on economic size and distance between two blocs. Research shows that there is overwhelming evidence that trade tends to fall with distance [6].

$$
\mathrm{Fij}=\mathrm{G} \frac{\mathrm{Mi} * \mathrm{Mj}}{\mathrm{Dij}}
$$

Where $\mathrm{G}$ is a constant, $\mathrm{F}$ is trade flow, $\mathrm{D}$ is distance, and $\mathrm{M}$ is the economic size of the countries measured.

For determining

$$
E x i j=\mathrm{A} \frac{G d p i * G d p j}{D i j}
$$

Exij denotes the foreign trade turnover between two countries as the sum of goods and services exported from $i$ to $j$ and imported by $i$ from $j$. GDPi and GDPj describe the respective gross domestic product of $\mathrm{i}$ and $\mathrm{j}$, and Dij represents the geographic distance between two countries. A is a constant.

Factors influencing trade cooperation are presented in Table 2.

Factors influencing trade cooperation are presented in Table

\begin{tabular}{|c|c|}
\hline Positive & Negative \\
\hline bilateral and multilateral trade agreements; & $\begin{array}{l}\text { детерминанты торговой политики: тарифы, } \\
\text { барьеры, квоты, субсидия; }\end{array}$ \\
\hline $\begin{array}{l}\text { availability of trade organizations: WTO; } \\
\text { EAEU }\end{array}$ & cultural differences between countries; \\
\hline \multirow[t]{2}{*}{$\begin{array}{l}\text { political order (the more liberal the countries } \\
\text { are, the more intensive the trade is). }\end{array}$} & historical determinants: armed conflicts; \\
\hline & Political differences, sanctions \\
\hline
\end{tabular}

Table 2. Positive and negative factord.

The least squares method is usually used to estimate the parameters. It is assumed that there is a linear relationship between variables and parameters. To establish a linear relationship, the formula takes the form of a logarithmic one:

$$
\ln E x i j=\ln A+\alpha \cdot \ln G D P i+\beta \cdot \ln G D P j-\gamma \cdot \ln D i j
$$

To increase its effectiveness, the formula can be expanded with additional influencing factors such as membership in a free trade zone, common borders and a common language. Ecometric estimation of the gravity equation introduces the following parameters:

$\ln E x i j=\ln A+0,54 \cdot \ln G D P i+0,81 \cdot \ln G D P j-0,89 \cdot \ln D i j+0,26 \cdot \operatorname{Limit}+0,61 \cdot$ Language $+1,06 \cdot$ Free Trade Zone (4)

A common border, a common language in which communication and document circulation are conducted, as well as the participation of two or more countries belonging to the free trade zone - all this is called dummy variables, which means that, if they are present, they take the value 1 . In the absence of such variables, their values are equal to 0 . The variables used in the gravity model were originally the GDP of countries involved in bilateral trade and the distance between their capitals as a proxy for transport costs, but other explanatory variables were added to the model shortly thereafter, the most used of which were: total border, common language, colonial ties (actual or historical ties between a country and a current or former colony) and membership in the Free Trade Agreement (FTA) [5].

Another important point in implementing large international projects is the personal and business qualities of managers who make management decisions. 
The results show that decision makers with an engineering background prefer startups with break-even profitability and focus less on the management team. In contrast, people with science education are particularly interested in the added value of a product or service, while people with a business background seem to value less the simplicity of international scalability [8].

The experience of China is an example of the successful implementation of international projects. In the PRC, the SEZ institute began to develop in the late 70s of the last century. 40 years later, China underwent a transition from labor-intensive exports to capital-intensive and high-tech exports [9].

\section{Conclusions}

Large international cooperative projects aimed at creating regional infrastructure make it possible to solve several problems of the Sustainable Development Goals promoted by the UN. Economic cooperation and interaction between stakeholders of the international project for the production of water desalination and wastewater treatment plants is promising and mutually beneficial, providing strong international trade chains. Availability of a raw material base, SEZs with a certain set of benefits and preferences, foreign and national investments are the key to a synergistic combination of industrial sectors and research centers, which provides an increase in jobs in different countries, the development of regional financial systems. Opening the production will allow efficient use of water resources, improve the environmental situation in the regions of the planet.

\section{References}

1. Katharina Pistor, Accounting, Economics, and Law: A Convivium, 11(1), 1 (2021)

2. Tamás Vasvári, Acta Oeconomica, 70(4), 571 (2020)

3. Zoltán Nadobán The Core-Periphery Divide in the European Union - A Dependency Perspective - Society and Economy, 43(1) (2020)

4. He Y., Fullerton T.M. Jr., Agric. Econ. - Czech, 66, 413 (2020)

5. A. Tamaș, D. Miron, Amfiteatru Economic, 23(56), 276 (2021)

6. Céline Carrère, Monika Mrázová, J. Peter Neary, The Economic Journal, 130(628), 880 (2020)

7. Danny Campbell, Erlend DanCke SanDorf, Bio-based and Applied Economics, 9(3), 305 (2020)

8. A. Moritz, W. Diegel, J. Block, J Bus Econ (2021)

9. Caporale Guglielmo Maria, Sova Anamaria, Sova Robert, China Economic Review, 34, 261 (2015)

10. Goal 9: Build resilient infrastructure, promote inclusive and sustainable industrialization and innovation, https://www.un.org/

11. Water Desalination Market by Technology (Reverse Osmosis, Multi-stage Flash Distillation, Multi Effect Distillation, Hybrid, Electrodialysis), Source (Seawater, Brackish Water) and Region, Global Forecasts 2018 to 2025, https://www.adroitmarketresearch.com/

12. Wastewater Treatment Services Market by Type (Design \& Engineering Consulting, Building \& Installation, Operation \& Process Control, Maintenance \& Repair), End User (Municipal, Industrial), and Region - Global Forecast to 2024 https://www.marketsandmarkets.com/ 